Date: 08 Desember 2021

\title{
SOSIO ANTROPOLOGI HUBUNGAN SOSIO ANTROPOLOGI BUDAYA, GIZI, DAN KESEHATAN
}

\author{
Moch Nur Azis (70200121056) \\ KESMAS A \\ Prodi Kesehatan Masyarakan, FKIK, UIN \\ Alauddin Makassar \\ Email : ambyarakutuh@gmail.com
}

\section{PENGARUH BUDAYA TERHADAP PANGAN}

Adanya sistem pengklasifikasian makanan tersebut tidak didasarkan atas konsep biokomiawi mengenai kandungan gizi makanan, tetapi didasarkan atas kesepakatan yang telah ditanamkan sejak dini kepada seseorang melalui proses sosialisasi dan enkulturasi dalam keluarga dan masyarakatnya (Jellife dalam Helman 1986). Sistem pengklasifikasian yang demikian itu, tidak hanya mengkondisikan adanya perbedaan jenis makanan yang tercakup dalam masing-masing kategori makanan pada setiap satuan kebudayaan, tetapi juga dapat mengkondisikan terjadinya ketidakseimbangan gizi. Disamping itu makanan kadang ditafsirkan dari kuantitasnya bukan kualitasnya, karena itu kekurangan gizi dapat terjadi pada tempat-tempat yang sebenarnya makanan relatif cukup tersedia. Dalam kaitan itu, menurut Foster (1986) kekurangan gizi dapat terjadi akibat pandangan yang keliru dalam menilai hubungan positif antara susunan makanan yang baik dengan status kesehatan yang baik, namun yang terjadi adalah pandangan mereka terhadap hubungan yang negatif antara makanan dan kesehatan. Artinya; orang yang sehat diperbolehkan untuk mengkonsumsi berbagai jenis makanan, namun karena keadaan sakit membatasi pilihanpilihan mereka terhadap makanan, dimana makanan tersebut sangat dibutuhkan oleh pasien. Selain itu, kekurangan gizi juga diakibatkan oleh adanya berbagai kepercayaan budaya dan pantangan-pantangan yang sering membatasi pemanfaatan makanan yang tersedia dilingkungannya.

\section{SISTEM BUDAYA TERHADAP MAKANAN}

Sistem budaya terhadap makanandapat dilihat dari berbagai aspek, yaitu;(1) Sifat makanan (Larangan makan makanan tertentu). Misalnya larangan mengonsumsi daun kelor bagi wanita yang hamil muda karena dipercaya dapat menggugurkan kandungannya. Kelor atau biasa disebut Moringa terdiri atas beberapa bagian, mulai dari akar, kulit kayu, bunga, hingga daun. Beberapa bagiannya seperti akar, bunga, dan kulit kayu diketahui tidak aman untuk dikonsumsi baik saat kehamilan maupun ketika menyusui. Hal ini karena kandungannya bisa membuat rahim berkontraksi. Ini bisa membuat ibu hamil mengalami keguguran, khususnya 
bila kehamilan masih berada dalam usia yang muda. Namun sebetulnya, kandungan gizi yang terdapat pada daun kelor memiliki asupan yang dibutuhkan oleh tubuh. Seperti protein, Vitamin, dan antioksidan, namun perlu juga dibatasi puntuk konsumsi sehari-hari agar kandungan gizi yang terdapat di dalamnya dapat membawa kebaikan bagi tubuh. (2) Hidangan makanan (menyajikan makanan pada kegiatan tertentu seperti upacara adat).

Misalnya tradisi Puputan di Jawa. Tradisi puputan merupakan tradisi yang dilakukan dalam rangkaian kelahiran seorang anak. Upacara ini menandai putusnya tali pusar si bayi (puput artinya lepas). Waktu untuk penyelenggaraan upacara ini tidak ada ketentuan yang pasti, hal ini bergantung pada lama dan tidaknya tali pusar si bayi lepas dengan semdirinya. Tali pusar bayi dapat lepas sebelum seminggu bahkan bisa lebih dari seminggu. Sehingga keluarga si bayi harus siap mengadakan upacara puputan jika sewaktu-waktu tali pusar tersebut lepas.

Biasanya, tradisi ini diselenggarakan dengan mengadakan kenduri atau selamatan yang dihadiri oleh kerabat dan tetangga terdekat. Sesajian (makanan) yang disediakan dalam upacara puputan antara lain nasi gudangan yang terdiri dari nasi dengan lauk pauk, sayurmayur dan parutan kelapa, bubur merah, bubur putih dan jajan pasar. (3) Mengonsumsi makanan dalam keluarga (pemerataan). Distribusi makanan dalam keluarga sangat berpengaruh terhadap kualitas gizi dalam keluarga. Misalnya pada saat bayi, sang ibu paham betul akan pentingnya pemberian ASI kepada bayi untuk menunjang pertumbuhan nya selama dua tahun. Namun pendistribusian makanan dalam keluarga ini juga dapat dipengaruhi oleh pengetahuan dan wawasan mengenai gizi, serta faktor ekonomi penunjangnya.

\section{MASALAH BUDAYA DAN MAKANAN TERHADAP GIZI}

Dilihat dari budaya dan makanan terhadap gizi, Sama seperti suku minangkabau, sunda, jawa dan suku-suku lainnya, suku bugis juga memiliki pola makan yang khas. Dalam kehidupan sehari-hari, Suku bugis sering mengkonsumsi ikan yang masih segar dengan nasi sebagai tambahan gizi karbohidrat. Namun sayangnya, dalam mengkonsumsi sayur dan buah mereka tergolong kurang. Kebiasaan makan suku bugis diturunkan dari nenek moyang terdahulu suku bugis bone. Nenek moyang suku bugis Bone tersebar di dataran rendah yang bekerja sebagai petani dan nelayan. Dari budaya tersebut terbentuklah kebiasaan makan suku bugis yang menjadikan ikan dan nasi sebagai makanan pokok hingga sekarang menjadi kebiasaan makan suku bugis dimanapun itu (Hengki, 2018)

Seperti halnya dengan suku lain, masyarakat Bugis Bone juga memiliki makanan dan minuman tradisional yang tetap diwariskan turun-temurun. Ada berbagai macam makanan dan minuman tradisional khas suku bugis salah satunya adalah Makanan Langka' dan burasa' merupakan makanan yang paling khas bagi masyarakat Bugis dimanapun mereka berada dan sering ditemui pada penjual kaki lima di pinggir jalan, demikian juga masyarakat Bugis Bone tetap melestarikan makanan khasnya hingga kapanpun.

Jumlah makan adalah banyaknya makanan yang dimakan setiap orang atau setiap individu dalam kelompok. Pada etnis bugis, mereka memakan makanan nasi dan lauk pauknya sehari tiga kali ditambah selingan segelas kopi, teh, susu atau buah-buahan. Pada pagi hari mereka memakan makanan tinggi karbohidrat seperti nasi, ikan segar yang dimasak sesuai selera yang mengandung proten tinggi dan sop sudara yang mengandung lemak hewani jika ditambah selingan pagi berupa buah-buahan akan mencukupi kebutuhan gizi makro dan beberapa gizi mikro yang terdapat dalam buah-buahan.

Saat makan siang pada beberapa etnis bugis mereka memakan burasa (50 gram) atau lontong (100 gram) dan soto makasar yang 100 gram per mangkok mempunyai kalori sebesar 285 Kalori. Burasa atau lontong adalah beras yang dikukus dengan dibungkus daun pisang 
sedangkan soto makasar mengandung protein hewani (35\%) dan lemak hewani (47\%).

Saat makan malam beberapa etnis bugis memakan buras atau nasi, ikan segar yang dimasak sesuai selera contohnya ikan goreng dan sop saudara. Berat burasa yang ukuran kecil per bijinya sekitar 50 gram, ikan goreng bandeng ukuran porsi 100 gram dengan 233 Kalori dan satu mangkok sop konro yang mengandung Kadar air per 100 gram sup konro adalah 85 g. Komponen lain yang terkandung dalam setiap sup konro adalah protein 7,4 g, lemak 2,6 g, karbohidrat 4,5 g, kalium $17 \mathrm{mg}$, fosfor $60 \mathrm{mg}$, besi 4,6 mg, kalium $25 \mathrm{mg}$, seng 1,3 mg, vitamin B1 0,12 mg, vitamin B2 0,02 mg, dan niasin 10,9 mg (Kemenkes RI, 2017).

\section{SOLUSI MENGATASI MASALAH BUDAYA DAN MAKANAN TERHADAP GIZI DAN KESEHATAN}

Dengan munculnya berbagai masalah terkait kekurangan maupun kelebihan gizi yang disebabkan oleh budaya dan makanan, maka solusi yang dapat dipakai yaitu dengan memperbaiki cara budaya dan makanan yang dikonsumsi dari yang kurang sehat menjadi lebih sehat dan bernutrisi. Misalnya pada saat ini budaya mengonsumsi makanan siap saji (junk food) banyak terjadi di perkotaan yang masyarakatnya dinamis dan membutuhkan sesuatu yang instan. Maka hal tersebut tentu mendatang berbagai masalah kesehatan seperti obesitas, jantung koroner, dan sebagainya. Maka solusi yang dapat diterapkan pada kasus ini adalah dengan melakukan pendekatan sosial serta penyuluhan akan makanan yang bergizi dan seimbang serta menciptakan tren gaya hidup sehat melalui berbagai media, salah satunya media sosial, pada saat ini penggunaan media sosial sudah tidak dapat dipisahkan dari kehidupan masyarakat khususnya di perkotaan, maka dari itu melakukan kampanye hidup sehat melalui media sosial cukup efektif untuk mengedukasi masyarakat tentang budaya dan makanan yang bergizi untuk tubuh. Selanjutnya yaitu dapat melakukan seminar, seminar ini memberikan kita ruang untuk menyampaikan hal-hal yang berkaitan dengan kesehatan dan gizi masyarakat secara langsung serta dapat melakukan tanya jawab langsung untuk mencari solusi terhadap suatu penyakit yang berkaitan dengan masalah gizi dan kesehatan. Selain itu juga terdapat upaya pemerintah dalam menangani masalah gizi di Indonesia berupa, Perbaikan Gizi Keluarga (UPGK) merupakan bentuk upaya yang dilakukan Pemerintah Indonesia melalui Badan Perencanaan Pembangunan Nasional (Bappenas). UPGK merupakan upaya yang dilakukan untuk memperbaiki gizi masyarakat. 


\section{DAFTAR PUSTAKA}

Ibrahim, Irvani Anwar, Syamsul Alam dkk. 2021. "Hubungan Sosial Budaya Dengan Kejadian Stunting Pada Balita Usia 24-59 Bulan Di Desa Bone-Bone Kecamatan Baraka Kabupaten Enrekang Tahun 2020", https://scholar.google.com/citations?view_op=view_citation\&hl=id\&user=5xW4cx4AAAAJ \&citation for view=5xW4cx4AAAAJ:kNdYIx-mwKoC, diakses pada tanggal 8 Desember 2021 pukul 20.29 WITA.

Sari, Siska Permata.2019. "4 Cara Pemenuhan Gizi Untuk Mencegah Stunting Dan Obesitas" , https://www.inews.id/lifestyle/health/4-cara-pemenuhan-gizi-untuk-mencegah-stunting-danobesitas, diakses pada tanggal 8 Desember 2021 pukul 20.49 WITA.

Kemenkes RI. 2017. Tabel Komposisi Pangan Indonesia. Jakarta: Kementrian Kesehatan RI

Ramadani, A. 2017. Hubungan Jenis, Jumlah dan Frejuensi Makan dengan Pola Buang Air Besar dan Keluhan Pencernaan pada Mahasiswa Muslim Puasa Ramadhan. Skripsi.

Umrahwati, 2018. Kebiasaan Makan Suku Bugis Bone di Sulawesi Selatan. Jurnal Nutrition Publich Health. 2(1)

Wijaya, H. 2018. Mengenal Budaya Suku Bugis Pendekatan Misi Terhadap Suku Bugis. Jurnal Lembaga STAKN Kupang. 6(2) 